\title{
CONTRIBUTORS
}

Ben Goldman is Digital Programs Archivist at the American Heritage Center, the University of Wyoming's repository of manuscript collections, rare books, and university archives. He received his MLS from Syracuse University, with a certificate in Digital Libraries.

Holly Mengel is the Project Manager for the Philadelphia Area Consortium of Special Collections Libraries "Hidden Collections" Processing Project administered by the Council on Library and Information Resources. She has a BA in history from Dickinson College and an MLIS with a concentration in archives from the University of Pittsburgh School of Information Sciences.

Margaret F. Nichols is the Rare Materials Cataloging Coordinator at Cornell University Library, where she has worked since 1985. She is currently the head of the RBMS Bibliographic Standards Committee editorial team developing DCRM(MSS), Descriptive Cataloging of Rare Materials (Manuscripts).

Katherine M. Wisser is Assistant Professor at the Graduate School of Library and Information Science faculty at Simmons College. She has previously served as the Director of Instructional Services at the School of Information and Library Science, University of North Carolina at Chapel Hill and at other institutions. She has a master's degree in American History from the University of New Hampshire, an MLS from the University of North Carolina at Chapel Hill, and a Ph.D. in Information Science from UNC.

\section{Broadsides Collection for Sale}

The Poetry Center of Chicago has an exceptional collection of broadsides for sale. Billy Collins, Kay Ryan, Louise Gluck, Lawrence Ferlinghetti, and many more, as well as prominent emerging poets. Images by noted artists, such as Ed Paschke, Tony Fitzpatrick. Limited letterpress printings of 50 and 100 copies on fine archival papers. Many poems original to the broadside. Many in color. Many signed. Presently in several university library collections (Yale, Emory, Brown). On view in the Store at poetrycenter.org. Please contact Don Chatham at dchatham@sbcglobal.net (630-479-0885) or Arica Hilton at aricahilton@mindspring.com (312-852-8200). 